\title{
PHYLOGENETIC CHARACTERIZATION OF BOVINE PARAINFLUENZA 3 FROM CONTAMINATED CELL CULTURES AND FIELD ISOLATES FROM BRAZIL
}

\author{
Rodrigo de Almeida Vaucher ${ }^{1}$, Diogenes Dezen ${ }^{2,3}$, Amauri Braga Simonetti ${ }^{4}$, Fernando Rosado Spilki ${ }^{5^{*}}$, Paulo Michel \\ Roehe $^{3,4}$
}

${ }^{1}$ Centro Universitário Franciscano, Santa Maria, RS, Brasil; ${ }^{2}$ Fepagro Saúde Animal, Instituto de Pesquisas Veterinárias Desidério Finamor, Eldorado do Sul, RS, Brasil; ${ }^{3}$ Instituto Federal Catarinense, Concordia, SC, Brasil; ${ }^{4}$ Virologia, Departamento de Microbiologia, Instituto de Ciências Básicas da Saúde, Universidade Federal do Rio Grande do Sul, Porto Alegre, RS, Brasil; ${ }^{5}$ Laboratório de Microbiologia Molecular, Instituto de Ciências da Saúde, Universidade Feevale, Novo Hamburgo, RS, Brasil.

Submitted: November 16, 2010; Approved: June 06, 2011.

\begin{abstract}
Genomic fragments of the HN and L genes from Brazilian bovine parainfluenza 3 virus (bPIV-3) isolated as contaminants from cell cultures and clinical specimens were amplified by reverse transcription-polymerase chain reaction (RT-PCR), sequenced using specific degenerate primers and analyzed by phylogenetic comparison with reference strains of bPI3V. The Brazilian isolates revealed a high degree of genomic when compared to SF4/32 prototype strain, within the recently proposed genotype A of bPIV-3.
\end{abstract}

Key words: Bovine parainfluenza virus type 3, bPIV-3, phylogenetic analysis

Bovine parainfluenza virus type 3 (bPIV-3) is a member of Respirovirus genus of the family Paramyxoviridae, genetically and antigenically related to human parainfluenza virus type 3 (9). In cattle, bPIV-3 is associated to the clinical condition known as "Shipping fever", a disease characterized by fever, apathy, anorexia, sneezing, serous and mucous nasal discharges, usually related to stress induced by transportation of cattle $(3,19)$. Occasionally, it has also been associated to abortions $(11,19)$. The virus is spread worldwide $(8,10,20)$; in Brazil, bPIV-3 is endemically present - though seldom isolated - mainly linked to respiratory disorders $(4,5,7)$.

Bovine viral diarrhea virus (BVDV) is by far the most common and widely recognized virus contaminating cell cultures (1); however, other viruses may be present. Viral contaminants can interfere with diagnosis of viral infections, since its unnoticed presence can lead to interference with the growth of other viruses. Vaccine produced on contaminated cells may in turn be contaminated, leading to immunossupression, seroconversion or disease in the vaccinated animals. Other parainfluenza viruses were found as contaminants in cell culture (6). On the present study, bPI3V contamination of bovine and swine cells is reported, and the cell isolates were phylogenetically compared to field strains.

In view of the limited number of available isolates, to date no molecular studies on Brazilian bPIV-3 were conducted. In the present study, the HN and L genes of two Brazilian bPIV-3 
clinical isolates and another two bPI3V cell contaminants were partially sequenced and submitted to phylogenetic analyses.

Madin-Darby Bovine Kidney cells (MDBK, originally from ATCC, CCL-22) were used for virus production and assays. Cells were cultured according to usual methods (7). The bPVI-3 reference strain SF-4 (National Veterinary Laboratories Service, USA) was used as a positive control for RT-PCR tests. The bPVI-3 isolate DIO was recovered from nasal secretions of a calf with respiratory disease in Rio Grande do Sul, Brazil (7). Two other isolates were included, one from a case of bovine abortion occurred in the state of Goiás, Brazil (PG1775) and another recovered from an accidentally contaminated culture of MDBK cells (bPI3V/BR/cells). Another batch of Porcine kidney cells lineage (PK-15) showed also to be contaminated with this adventitious bPI3V isolate, and the virus was further isolated in non-contaminated MDBK cells. Strict biosafety measures were taken on the laboratory to avoid cross contamination.

All bPIV-3 isolates were cultured in virus-free MDBK cells following standard protocols (7). Viral RNA was extracted from viral stocks with Trizol (Invitrogen, Carlsbad, CA, USA) and chloroform, followed by sequential precipitations in 40\% isopropanol and 70\% ethanol (15).

Primers used were targeted to amplify bPIV-3 genomic fragments as proposed by (16). For cDNA synthesis, viral RNA $(1 \mu \mathrm{g})$ was reverse transcribed with 200 units of M-MLV reverse transcriptase (Invitrogen, Carlsbad, CA, USA) and 200 ng of sense degenerate primers. Polymerase chain reactions (PCR) and sequencing were performed as described elsewhere (18). The SF-4/32 viral strain cultured in non-contaminated MDBK cells was used as positive control and deionized water as negative control. Similarly, another PCR was conducted to amplify and sequence the L polymerase gene from the cell culture contaminants, bPI3V/cells/MDBK and bPI3V/cells/PK15 , to better infer whether they are genetically related. After purification and quantification, the PCR products were submitted to nucleotide sequence analysis. Sequencing was carried with the Big Dye Terminator Cycle Sequencing Ready Reaction (Applied Biosystems, UK) in an ABI-PRISM 3100 Genetic Analyzer (ABI, Foster City, CA), according to the manufacturer's protocol. Three repetitions were performed on each amplified genomic fragment.

The sequence of SF4/32 strain (accession number AF178655) and other PIV-3 sequences available at GenBank database (accession numbers EU277658, NC002161, AF178654, U31671, E01754, Y00114, E01755, AB18996, AB189960, AY283065, Z26523, L25350, X55803, X56131 and X02808) were used for comparison for $\mathrm{HN}$ region; sequences AF178654, AF178655, D84095, EU277658, EU439429, and EU326526 were used for the L gene. The BioEdit software, version 7.01 (Hall 1999) was used to manipulate the nucleotide and amino acid of retrieved bPIV-3 sequences. The alignment of sequences was performed using the ClustalW software, version 2.0 (13).

Phylogenetic reconstructions based on the alignment of the $\mathrm{HN}$ and L genes nucleotide sequences are shown on Figure 1. Both trees (Figure 1, A and B) were calculated using the Maximum Parsimony method, in a bootstrap of 500 replicates. All calculations were made in MEGA5 (17). Homologous sequences from hPI3V were included as outgroups.

All Brazilian cell contaminants and clinical isolates clearly clustered in the same group as the prototype vaccine strain SF4/32, within the recently proposed genotype A Since the 1980 's, when vaccination to bPI3V was introduced in Brazil, there are both live and killed vaccines marketed based on SF4 strain. One may consider that the isolates presented here may be related to the circulation of vaccine the field, which may be a possibility; however, those samples were collected from non-vaccinated cattle or were found as cell contaminants. This, together with the nucleotide differences found from the original SF4/32 strain, are indicating that those are wild bPI3V isolates.

Although the results presented here might be considered as preliminary, since they are based only in a few sequences, it 
can be seen in Figure 1 that genotype A may present two distinct sub-lineages, one related to the SF4/32 strain, another with the $910 \mathrm{~N}$ isolate; nevertheless, this have to be confirmed with a greater number of isolates. Analyzing the data collected on the present study, for the HN genomic portion, when isolates belonging to the same sub-lineage were compared intra-genotypically, a variation within the range 0.3 to $2.4 \%$ was recorded (with the exception of the variant isolate PG1775, $10.6 \%$ ). The overall level of inter-subgenotypical variation for the HN gene was higher (7.8-15\%) (Table1); however, the differences ranges for particular isolates do not fully support these conclusions, thus requiring further efforts on the collection and characterization of new bPI3V isolates. For the $\mathrm{L}$ gene, the identity for the analyzed genomic fragment was above $97 \%$ for strains inside the genotype A, and $84-89 \%$ between genotype B strains and viruses from genotype A. It is also suggestive that the isolates which were noticed as adventitious contaminat were virtually the same virus, since the sequences were highly similar. Isolation of bPI3V as a contaminant in cell cultures may be another matter of concern for laboratories dealing with research and diagnosis of bovine viral respiratory infections, or vaccine production, since the cytopathic effect of the virus is sometimes very discrete.

These findings provide additional evidence for diversity among bPI3V genotype A isolates, in agreement with previous reports based on antigenic and phenotypic analyses with monoclonal antibodies $(2,12-14)$. The impacts of this genomic diversity on the clinical pictures and preventive measures, especially vaccination, remain to be determined in the future.

(A) $\mathrm{HN}$

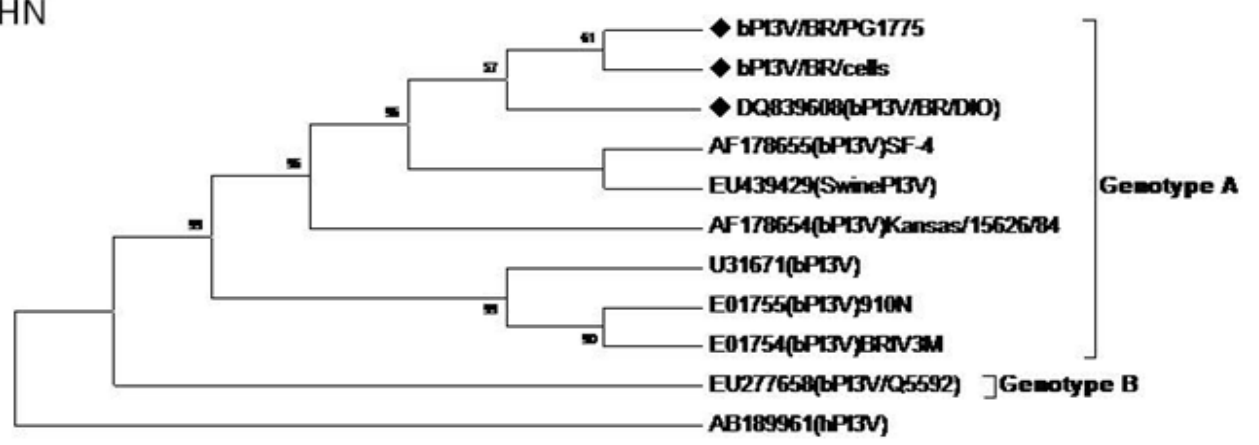

(B) L

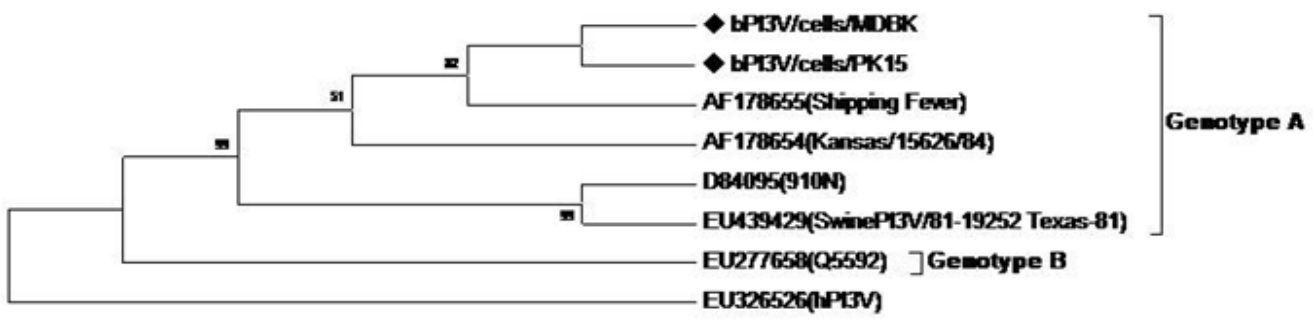

Figure 1. Evolutionary relationship between bovine parainfluenza type 3 viruses (bPIV-3), as inferred from partial sequences of the gene HN (A) and L (B). The neighbor-joining method was used; only bootstrap values higher than 50 are shown. Brazilian strains (black lozenges) clustered together with the prototype strain SF4/32. The two distinguishable subgenotypes among bPIV-3 genotype A isolates are shown. Human PIV-3 was used as an out-group. 
Table 1. Identity percentages among partial nucleotide sequences (nucleotide positions 305 to 660) of the hemagglutininneuraminidase $(\mathrm{HN})$ gene from different bovine parainfluenza virus type 3 (bPI3V) isolates. Human PI3V was considered as an out-group.

\begin{tabular}{|c|c|c|c|c|c|c|c|c|c|c|c|}
\hline & $\begin{array}{c}\text { AF178655 } \\
\text { (bPI3V)SF-4 }\end{array}$ & $\begin{array}{l}\text { DQ839608 } \\
\text { (bPI3V/BR/l } \\
\text { DIO) }\end{array}$ & $\begin{array}{l}\text { bPI3V/BR/P } \\
\text { G1775 }\end{array}$ & $\begin{array}{c}\text { bPI3V/ } \\
\text { BR/cells }\end{array}$ & $\begin{array}{c}\text { EU439429 } \\
\text { (SwinePI3V) }\end{array}$ & $\begin{array}{l}\text { U31671 } \\
\text { (bPI3V) }\end{array}$ & $\begin{array}{c}\text { AF178654 } \\
\text { (bPI3V)Kansas } \\
\text { /15626/84 }\end{array}$ & $\begin{array}{c}\text { E01755( } \\
\text { bPI3V) } \\
10 N\end{array}$ & $\begin{array}{c}\text { E01754 } \\
\text { (bPI3V)B } \\
\text { RIV3M }\end{array}$ & $\begin{array}{c}\text { EU277658 } \\
\text { (bPI3V/Q5 } \\
592)\end{array}$ & $\begin{array}{c}\text { AB1899 } \\
61 \\
\text { (hPI3V) }\end{array}$ \\
\hline AF178655(bPI3V)SF-4 & - & 99.4 & 92.4 & 98.3 & 99.7 & 92.4 & 97.4 & 91.9 & 91.3 & 81.3 & 75.2 \\
\hline DQ839608(bPI3V/BR/DIO) & 99.4 & - & 93 & 98.3 & 99.7 & 92.4 & 97.4 & 91.9 & 91.3 & 81.3 & 75.2 \\
\hline bPI3V/BR/PG1775 & 92.4 & 93 & - & 92.2 & 92.7 & 85.7 & 90.5 & 85.7 & 85.2 & 75.4 & 69.3 \\
\hline bPI3V/BR/cells & 98.3 & 98.3 & 92.2 & - & 98 & 90.8 & 95.8 & 90.2 & 89.6 & 79.9 & 73.8 \\
\hline EU439429(SwinePI3V) & 99.7 & 99.7 & 92.7 & 98 & - & 92.7 & 97.7 & 92.2 & 91.6 & 81.6 & 75.4 \\
\hline U31671(bPI3V) & 92.4 & 92.4 & 85.7 & 90.8 & 92.7 & - & 92.2 & 99.1 & 98.8 & 83.2 & 75.7 \\
\hline $\begin{array}{l}\text { AF178654(bPI3V) } \\
\text { Kansas/15626/84 }\end{array}$ & 97.4 & 97.4 & 90.5 & 95.8 & 97.7 & 92.2 & - & 91.6 & 91 & 82.7 & 76.3 \\
\hline E01755(bPI3V)910N & 91.9 & 91.9 & 85.7 & 90.2 & 92.2 & 99.1 & 91.6 & - & 99.1 & 83.5 & 75.2 \\
\hline E01754(bPI3V)BRIV3M & 91.3 & 91.3 & 85.2 & 89.6 & 91.6 & 98.8 & 91 & 99.1 & - & 83.2 & 74.9 \\
\hline EU277658(bPI3V/Q5592) & 81.3 & 81.3 & 75.4 & 79.9 & 81.6 & 83.2 & 82.7 & 83.5 & 83.2 & - & 74.9 \\
\hline AB189961(hPI3V) & 75.2 & 75.2 & 69.3 & 73.8 & 75.4 & 75.7 & 76.3 & 75.2 & 74.9 & 74.9 & - \\
\hline
\end{tabular}

\section{ACKNOWLEDGEMENTS}

Work supported by the Brazilian National Research Board (CNPq). PMR and FRS are CNPq research fellows.

\section{REFERENCES}

1. Audet, S.; Crim, R.; Beeler, J. (2000). Evaluation of vaccines, interferons and cell substrates for pestivirus contamination. Biologicals 28 (1), 4146.

2. Breker-Klassen, M.M.; Yoo, D.; Babiuk, L.A. (1996). Comparisons of the $\mathrm{F}$ and $\mathrm{HN}$ gene sequences of different strains of bovine parainfluenza virus type 3: relationship to phenotype and pathogenicity. Can. J. Vet. Res. 60 (3), 228-236.

3. Bryson, D.G.; Adair, B.M.; McNulty, M.S.; McAliskey, M.; Bradford, H.E.L.; Allan, G.M.; Evans, R.T.; Forster, F. (1999). Studies on the efficacy of intranasal vaccination for the prevention of experimentally induced parainfluenza type 3 virus pneumonia in calves. Vet. Rec. 145 (2), 33-39

4. Candeias, J.A.N.; Ribeiro, L.C. (1968). Anticorpos inibidores da hemaglutinação para o vírus parainfluenza 3 (Ha-1), em gado bovino. Rev. de Saúde Pública 2 (2), 180-185.

5. Candeias, J.A.N.; Washington Sugay, II, Ribeiro, L.C. (1971). Isolamento de Myxovirus parainfluenza 3 de gado bovino no Estado de São Paulo, Brasil. Rev. de Saúde Pública 5 (2), 207-212.
6. Crandell, R.A.; Hierholzer, J.C.; Krebs, J.W.; Jr, Drysdale, S.S. (1978). Contamination of primary embryonic bovine kidney cell cultures with parainfluenza type 2 simian virus 5 and infectious bovine rhinotracheitis virus. J. Clin. Microbiol.7 (2), 214-218.

7. Gonçalves, D.A.; Spilki, F.R.; Chiminazzo, C.; Oliveira, M.A.; Franco, A.C.; Roehe, P.M. (2003). Isolamento do vírus Parainfluenza bovino tipo 3 no Rio Grande do Sul, Brasil. Ciencia Rural 33 (5), 953-956.

8. Hartel, H.; Nikunen, S.; Neuvonen, E.; Tanskanen, R.; Kivela, S.L.; Aho, R.; Soveri, T.; Saloniemi, H. (2004). Viral and bacterial pathogens in bovine respiratory disease in Finland. Acta Vet. Scand. 45 (3-4), 193200.

9. Henrickson, K.J. (2003). Parainfluenza Viruses. Clin. Microbiol. Rev. 16 (2), 242-264.

10. Horwood, P.F.; Gravel, J.L.; Mahony, T.J. (2008). Identification of two distinct bovine parainfluenza virus type 3 genotypes. J. Gen. Virol. 89 (7), 1643-1648.

11. Kirkbride, C.A. (1992). Viral agents and associated lesions detected in a 10 -year study of bovine abortions and stillbirths. J. Vet. Diag. Invest. 4 (4), 374-379.

12. Klippmark, E.; Rydbeck, R.; Shibuta, H.; Norrby, E. (1990). Antigenic variation of human and bovine parainfluenza virus type 3 strains. J. Gen. Virol. 71 (7), 1577-1580.

13. Larkin, M.A.; Blackshields, G.; Brown, N.P.; Chenna, R.; McGettigan, P.A.; McWilliam, H.; Valentin, F.; Wallace, I.M.; Wilm, A.; Lopez, R.; Thompson, J.D.; Gibson, T.J.; Higgins, D.G. (2007). Clustal W and Clustal X version 2.0. Bioinformatics 23 (21), 2947-2948.

14. Rydbeck, R.; Love, A.; Orvell, C.; Norrby, E. (1987). Antigenic analysis 
of Human and Bovine parainfluenza virus type 3 strains with monoclonal antibodies. J. Gen. Virol. 68 (8), 2153-2160.

15. Sambrook, J.; Russell, D.W. 2001. Molecular Cloning: A Laboratory Manual. CSHL Press, New York, 1448 p.

16. Stokes, A.; Tierney, E.L.; Murphy, B.R.; Hall, S.L. (1992). The complete nucleotide sequence of the JS strain of human parainfluenza virus type 3 : comparison with the Wash/47885/57 prototype strain. Virus Res. 25 (7), 91-103.

17. Tamura, K.; Dudley, J.; Nei, M.; Kumar, S. (2007). MEGA4: Molecular Evolutionary Genetics Analysis (MEGA) Software Version 4.0. Mol.
Biol. Evol. 24 (8), 1596-1599.

18. Vaucher, R.A.; Simonetti, A.B.; Roehe, P.M. (2008). RT-PCR for detection of bovine parainfluenza virus type 3 (bPIV-3). Acta Sci. Veterinarie 36 (3), 215-220.

19. Yates, W.D. (1982). A review of infectious bovine rhinotracheitis, shipping fever pneumonia and viral-bacterial synergism in respiratory disease of cattle. Can. J.Comp. Med. 46 (3), 225-263.

20. Yesilbag, K.; Gungor, B. (2008). Seroprevalence of bovine respiratory viruses in North-Western Turkey. Trop. Anim. Health Prod. 40 (1), 5560.

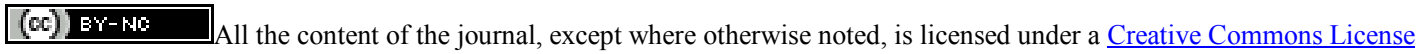

